\title{
STUDIES ON THE MACROMOLECULAR AND ANTIGENIC COMPOSITION OF RABBIT SEMINAL PLASMA
}

\author{
G. YANTORNO, MIGUEL A. VIDES AND ELSA VOTTERO-CIMA
}

Cátedra de Inmunología y Serología and Cátedra de Quimica Clínica, Departamento de Bioquímica Clínica, Facultad de Ciencias Químicas, Universidad Nacional de Córdoba, Santa Rosa 1564, Córdoba, Argentina

(Received 20th April 1971, accepted 4th August 1971)

Summary. Ultracentrifugal studies of rabbit seminal plasma (RSP) showed a prominent $1 \cdot 85 \mathrm{~S}$ peak with a $4 \cdot 20 \mathrm{~S}$ shoulder and minor fast components. Seminal plasma subjected to molecular sieve through Sephadex G-100 showed marked heterogeneity. Using this procedure, five fractions were defined which contained several macromolecular components as revealed by polyacrylamide electrophoresis, agar gel immunoelectrophoresis and immunodiffusion assays.

Immunological studies on organ specificity using heteroantisera showed that RSP contains a mixture of genital-tract-specific antigens and several antigens shared with other organs and serum. Using selected autoantisera, the presence was demonstrated of two distinct autoantigens specific to the rabbit accessory glands and additional autoantigens from testis and/or epididymis proving the complex autoantigenic nature of RSP.

\section{INTRODUCTION}

Previous reports have described the antigenic and/or biophysical properties of rabbit semen (Weil \& Finkler, 1958; Kirton, Desjardins \& Hafs, 1966; Menge \& Protzman, 1967; Hunter, 1969; Hunter \& Nornes, 1969). Immunological studies using heteroantisera showed a variety of antigens in rabbit seminal plasma (RSP), some of which behaved as sperm specific (Menge \& Protzman, 1967; Hunter, 1969). Using sera from rabbits isoimmunized with seminal plasma, at least one component was shown to be antigenically active (Weil \& Finkler, 1959). More recently, utilizing sera from rabbits isoimmunized with male accessory glands (Shulman, Yantorno, Soanes, Gonder \& Witebsky, 1966) or seminal plasma (Shulman, Riera \& Yantorno, 1968), it was found that the latter contained specific autoantigen(s) derived from the male accessory glands. Similar results were obtained when cryosurgery of these glands was used as an alternative procedure to autoimmunization (Yantorno, Soanes, Gonder \& Shulman, 1967; Shulman, Brandt \& Yantorno, 1968). The ability of seminal plasma to induce allergic orchitis in rabbits has been recently reported (Yantorno, Debanne \& Vottero-Cima, 1971). 
The present report gives the results of an attempt to describe and correlate the macromolecular and immunological heterogeneity of RSP, giving special attention to the identification of components showing autoantigenic properties.

\section{MATERIALS AND METHODS}

\section{Rabbit seminal plasma}

Ejaculated semen was obtained by means of the artificial vagina (Bredderman, Foote \& Yassen, 1964) from sexually mature crossbred Flemish Giant and New Zealand rabbits, weighing 4 to $5 \mathrm{~kg}$. A number of individual samples or pools of semen were centrifuged at $12,300 \mathrm{~g}$ for $15 \mathrm{~min}$ at $4^{\circ} \mathrm{C}$ after collection in order to obtain the seminal plasma. All specimens were processed immediately or stored at $-18^{\circ} \mathrm{C}$ until use.

\section{Fractionation of rabbit seminal plasma}

The gel fltration method. Cross-linked dextran gel Sephadex G-100 (Pharmacia, Uppsala, Sweden) was prepared according to the manufacturer's instructions. The buffer consisted of $0 \cdot 1 \mathrm{~m}$-tris- $\mathrm{HCl} \mathrm{pH} 8+1 \mathrm{M}-\mathrm{NaCl}$ (Killander, 1964). To prevent proteolytic activity, 0.001 M-EDTA was added to the buffer (Vides, 1969). The volume of the gel bed was $2.6 \times 113 \mathrm{~cm}$. After applying $150 \mathrm{mg}$ RSP proteins, the elution was performed with the buffer used for equilibration at flow rate of 8 to $10 \mathrm{ml} / \mathrm{hr}$ at room temperature. The effluent was collected in 3-ml portions and protein distribution was determined by u.v. absorbancy at $280 \mathrm{~m} \mu$. All fractions eluted from the columns were first dialysed against distilled water and were then freeze dried.

Column chromatography on anion exchanger. DEAE-Sephadex A-50 was prepared as recommended by the manufacturer's instructions and then equilibrated with initial eluant buffer of 0.05 м-tris-HCl pH $8+0.001$ m-EDTA until the effluent acquired the correct $\mathrm{pH}$ and counter ion concentration. The volume of the gel bed was $1.5 \times 50 \mathrm{~cm}$. After applying the sample, elution of the column was performed by a stepwise increasing concentration of $\mathrm{NaCl}(0.0,0.1,0.5,1.8 \mathrm{M})$ in $0.05 \mathrm{M}$-tris-HCl buffer $\mathrm{pH} 8+0.001 \mathrm{M}$-EDTA, at the flow rate 6 to $8 \mathrm{ml} / \mathrm{hr}$ at room temperature. Then the procedure described for gel filtration was followed.

\section{Extract preparation}

Saline extracts of all specimens of tissue used were prepared as described previously (Shulman et al., 1966).

\section{Heterologous antisera}

A sheep, weighing approximately $120 \mathrm{lb}$, was immunized by an intradermal injection of $1 \mathrm{ml}$ pooled fresh rabbit semen emulsified in $1 \mathrm{ml}$ Freund's complete adjuvant. For the initial injection, a total of $8 \mathrm{mg}$ killed Mycobacterium tuberculosis $/ \mathrm{ml}$ of adjuvant was used. In each succeeding injection, the amount of Mycobacterium was decreased by $2 \mathrm{mg} / \mathrm{ml}$ until standard complete adjuvant was used. Two months after the fourth injection, $2 \mathrm{ml}$ of semen emulsified in an equal volume of Freund's adjuvant containing $8 \mathrm{mg}$ bacilli $/ \mathrm{ml}$ were injected. Bleedings were obtained by venepuncture 8 and 12 days after the third and 
fourth injections and 10 days after the final booster dose. The sera obtained, called sheep anti-rabbit semen serum ' $a$ ', ' $b$ ' and 'c' respectively, were stored at $-18 \pm 2^{\circ} \mathrm{C}$ until use. Absorbed antisera were prepared by adding $200 \mathrm{mg}$ of freeze-dried rabbit serum and eventually $100 \mathrm{mg}$ of freeze-dried epididymal extract. These were incubated at $37^{\circ} \mathrm{C}$ for $1 \mathrm{hr}$, placed at $4^{\circ} \mathrm{C}$ overnight, and then centrifuged at $12,300 \mathrm{~g}$ for $30 \mathrm{~min}$.

Guinea-pig anti-rabbit semen and anti-rabbit IgG sera were prepared, following an immunization schedule similar to that described above although the total volume for each injection was $1 \mathrm{ml}$. Rabbit IgG used for immunization was purified according to the method of Levy \& Sober (1960).

\section{Autologous and isologous antisera}

Antisera were also prepared by auto- or isoimmunization of rabbits with either native or chemically modified RSP incorporated to complete Freund's adjuvant according to a procedure described elsewhere (Yantorno, VotteroCima, Riera \& Vides, in preparation). Rabbit male accessory glands' extract was also used as immunizing material. Rabbit 134 anti-RSP (autoimmunized) and Rabbit 171 anti-RSP (isoimmunized) sera were used in most experiments.

\section{Electrophoretic analysis}

Starch-gel electrophoresis was performed in a vertical apparatus (Buchler \& Co.) following the procedure proposed by Smithies (1959) using 0.03 $\mathrm{M}$-boric acid buffer in the gel and $0.3 \mathrm{M}$-buffer in the vessels. Runs were performed at $100 \mathrm{~V}$ for $18 \mathrm{hr}$. Polyacrylamide gel electrophoresis was performed according to the procedure described by Davis (1964), in $9 \times 0.8 \mathrm{~cm}$ size gels with trisglycine buffer, applying a current of $2.5 \mathrm{~mA}$ per tube and noting the time required for rabbit serum albumin to migrate $4 \mathrm{~cm}$.

\section{Ultracentrifugation analysis}

Sedimentation constants of RSP were determined in a $0 \cdot 15 \mathrm{M}-\mathrm{NaCl}$ solution at different protein concentrations $(1.0,1.5$ and $2.0 \mathrm{~g} \%)$ in a Spinco Mod. E ultracentrifuge at $42,040 \mathrm{rev} / \mathrm{min}$ at $20^{\circ} \mathrm{C}$.

\section{Immunological tests}

Immunodiffusion. Double diffusion gel precipitation (Ouchterlony, 1948) was performed using $1.5 \%$ Difco Noble agar in $0.15 \mathrm{M}-\mathrm{NaCl}$ with $1: 10,000$ Merthiolate as preservative.

Immunoelectrophoresis. The microprocedure was carried out as described by Scheidegger (1955).

Passive haemagglutination and inhibition haemagglutination. The tanned cell haemagglutination method was that of Boyden (1951) as modified by Yantorno et al. (1967). For inhibition of tanned cell haemagglutination, $0.1 \mathrm{ml}$ of increasing dilutions of the test material being evaluated as an inhibitor was added to $0.1 \mathrm{ml}$ antiserum corresponding to 8 agglutinating units. The mixture was left for $30 \mathrm{~min}$ at room temperature, and then $0.1 \mathrm{ml}$ coated cells was added to each tube. Readings were taken at $2 \mathrm{hr}$ and $18 \mathrm{hr}$.

Inhibition of sperm immobilization. The sperm-immobilization test was performed 
as previously described (Yantorno, Debanne \& Vottero-Cima, 1971). For the inhibition of sperm immobilization, $0.1 \mathrm{ml}$ of the test material being evaluated as an inhibitor was added to $0.1 \mathrm{ml}$ sperm-immobilizing antiserum. After incubation at $37^{\circ} \mathrm{C}$ for $5 \mathrm{~min}, 0.1 \mathrm{ml}$ guinea-pig complement and $0.1 \mathrm{ml}$ sperm suspension were added. Inhibition was considered positive when sperm motility in this mixture was comparable to the motility observed with serum samples obtained before immunization.

\section{RESULTS}

\section{Macromolecular heterogeneity}

Ultracentrifugal studies of RSP showed a major slow and prominent peak which can be designated as the $1.85 \mathrm{~S}$ component. A second component with an estimated $4 \cdot 20 \mathrm{~S}$ appeared as a shoulder. Minor fast peaks were also detected in these studies.

Seminal plasma subjected to molecular sieve through Sephadex G-100 showed marked heterogeneity. A characteristic elution profile is presented in Pl. 1, Fig. 1. Pools corresponding to the main peaks were prepared as indicated in the graph. It can be seen that five fractions have been defined, the first corresponding to the excluded volume and the remaining four to different volumes of penetration in the gel. The fractions have been called FI, FII, FIII, FIV and FV, respectively. More than thirty runs performed with several pools of RSP gave patterns of remarkable similarity.

Starch-gel electrophoresis showed that RSP contains as many as ten components. Results are not presented in detail since electrophoretic studies using polyacrylamide as supporting medium proved to be of higher resolution. Using the latter procedure, fourteen protein bands were constantly detected in RSP. Typical patterns are illustrated in Pl. 1, Fig. 2 where a polyacrylamide gel column corresponding to rabbit serum is presented as reference. In the same figure, it can be seen that FI and FII, as expected, showed predominance of protein bands with relatively slow mobility. In contrast, FIII, FIV and FV contained major components with fast mobility.

Rabbit seminal plasma was also assayed by immunodiffusion using guineapig and sheep anti-rabbit semen sera. The latter proved to possess higher

\section{EXPLANATION OF PLATE 1}

Fig. 1. Sephadex G-100 gel filtration pattern of $150 \mathrm{mg}$ rabbit seminal plasma (RSP) proteins. Bed dimensions : $2 \cdot 6 \times 113 \mathrm{~cm}$. Eluant: $0 \cdot 1 \mathrm{M}$-tris-HC1 $\mathrm{pH} 8+1 \mathrm{M}-\mathrm{NaCl}+0 \cdot 001$ M-EDTA. Flow rate: 8 to $10 \mathrm{ml} / \mathrm{hr}$. Effluent portions: $3 \mathrm{ml}$. The short lines indicate the eluates pooled to make the designate fractions.

Fig. 2. Polyacrylamide gel electrophoresis ( $\mathrm{pH}$ 8.6) of RSP and its Sephadex G-100 fractions. The pattern of rabbit serum (RS) is shown for comparison.

FIg. 3. Gel diffusion precipitation pattern of RSP and its Sephadex G-100 fractions. Centre well: sheep anti-rabbit semen serum ' $c$ '. Peripheral wells: RSP $0.75 \%$; FI $2.0 \%$; FII $1.5 \%$; FIII and FIV $0.4 \%$; FV $0.1 \%$.

FIG. 4. Immunoelectrophoretic patterns of RSP and its Sephadex G-100 fractions used at the same concentration listed in Fig. 3. Sheep anti-rabbit semen serum ' $c$ ' was used for development of immunoprecipitin arcs.

Fig. 5. Gel diffusion precipitation patterns. Centre well: rabbit 171 anti-RSP. Peripheral wells : RSP $0.7 \%$; FI at $2.0 \%$ and $1.5 \%$; FII at 1.0 and $0.7 \%$. 
PLATE 1
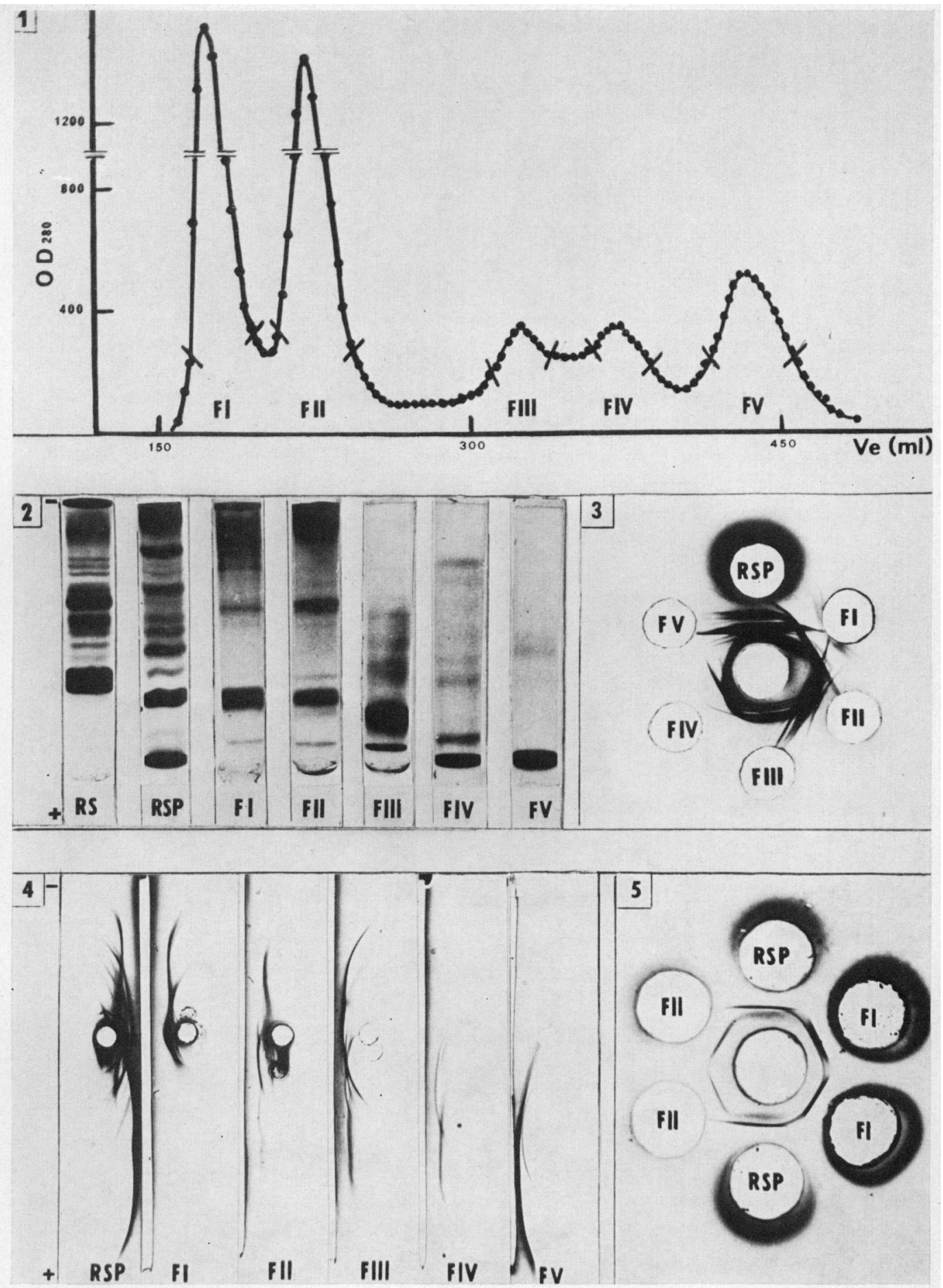

(Facing p. 232) 

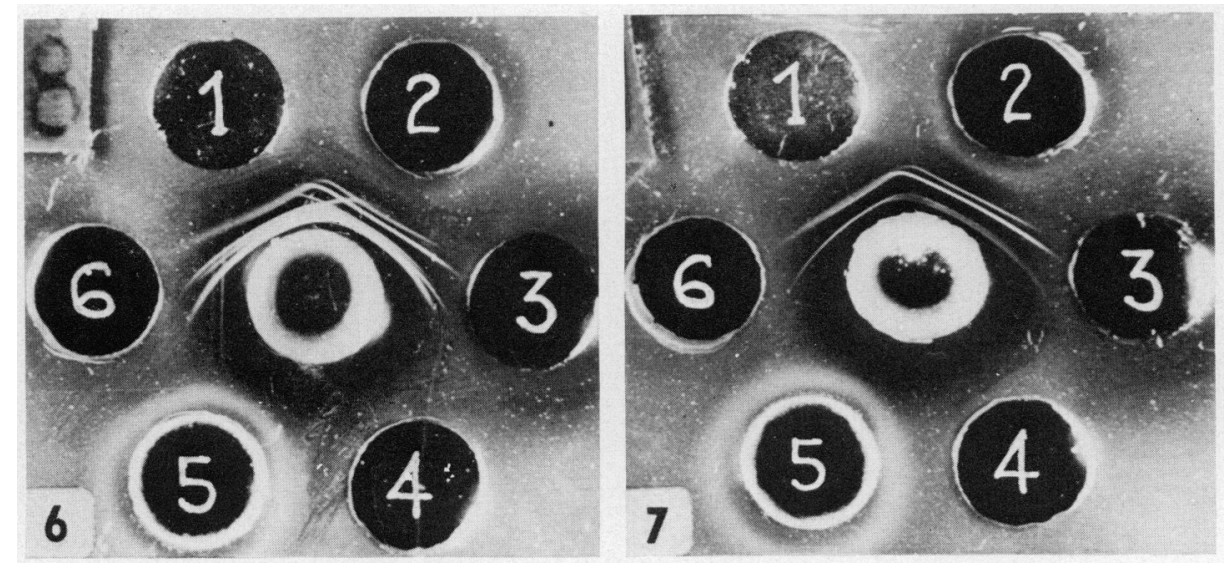

FIG. 6. Gel diffusion precipitation pattern. Centre well: sheep anti-rabbit semen serum 'c' absorbed with freeze-dried rabbit serum. Peripheral wells contain RSP $(0.5 \%)$ and saline extract of rabbit organs (approximately 2.0\%) as follows: (1) RSP; (2) male accessory glands; (3) spleen; (4) ovary; (5) testis; (6) epididymis.

FIG. 7. Gel diffusion precipitation pattern. Centre well: sheep anti-rabbit semen serum ' $c$ ' absorbed with freeze-dried rabbit scrum and freeze-dried rabbit epididymal extract. Peripheral wells: the same specimens listed in Fig. 6. 
discriminative power. After a preliminary evaluation, serum obtained from sheep ' $c$ ' was selected, and all subsequent experiments were performed using this antiserum. Several individual seminal plasma samples periodically obtained from seven rabbits showed that the main lines revealed in pooled seminal plasma were always present in at least one sample of a given individual, even though the relative antigenic concentrations varied widely, judging from their position in the precipitation field. Experiments performed using pooled RSP of approximately 2.0 to $2.5 \%$ protein concentration against sheep antiserum revealed two antigens which precipitated close to the antigen reservoir, suggesting its macromolecular nature (Korngold \& van Leevwen, 1957). Several distinct bands of precipitation were also consistently detected in the middle of the field. On the other hand, lines of precipitation which appeared close to the antiserum well were better defined when RSP was used at 1:10 or 1:15 dilutions. A representative experiment is presented in $\mathrm{Pl}$. 1, Fig. 3 where it can also be appreciated that as many as fourteen seminal plasma antigens are distributed among the Sephadex G-100 fractions.

Immunoelectrophoresis of pooled RSP revealed at least twelve antigenic components distributed along the fractions from Sephadex G-100 (Pl. 1, Fig. 4). When similar experiments were performed using the antiserum absorbed with freeze-dried rabbit serum, only nine lines appeared. Patterns were highly reproducible when different seminal plasma pools were used in complementary experiments.

\section{Organ specificity}

The immunochemical studies presented above suggest that antigens of the nature of those in serum were present in RSP along with a number of tissue antigens. Additional experiments proved that at least two serum-like antigens were present in all seven individual samples studied. One band of precipitation was identified as IgG using guinea-pig anti-rabbit IgG serum. This antiserum behaves as highly specific for rabbit IgG in immunodiffusion assays. Absorption of the sheep anti-rabbit semen serum with rabbit serum eliminated the lines corresponding to these antigens allowing the unequivocal demonstration of tissue antigens (PI. 2, Fig. 6). Several organs, other than that presented in this experiment, were studied, such as kidney, liver, heart, bladder, uterus, brain, thyroid, pancreas and salivary gland. It is interesting to note that some bands of precipitation appeared to be characteristic of a given organ whereas, in other cases, the antigen was shared between two or more tissues. In Pl. 2, Fig. 7, the reaction obtained when the antiserum was absorbed with freeze-dried rabbit serum and rabbit epididymis is presented. This procedure revealed the specific antigens of rabbit male accessory glands as proved in several additional immunodiffusion assays. Those specific antigens which precipitated in the middle of the field were later shown to be autoantigens. The organ-specific nature of the remaining antigens which precipitate close to the antiserum well was further explored by the haemagglutination method, using red cells coated with FV Sephadex G-100 and sheep antiserum absorbed with rabbit serum. Several organs were tested for inhibitor for this reaction. The results presented in Table 1 show that only seminal plasma, male accessory glands' extract and FV 
were able to inhibit the reaction. Thus, the fraction under study contained at least one organ-specific antigen. Similar results and conclusions were obtained when FIII was used as coating material. Inhibition of the haemagglutination test proved that FIII and FV contained two different specific antigens since the reaction of sheep antiserum against cells coated with FIII was not inhibited by FV.

TABLE 1

TANNED CELL HAEMAGGLUTINATION INHIBITION TEST*

\begin{tabular}{c|c|c|c|c|c}
\hline \multicolumn{5}{|c}{ Reciprocal titre of the inhibiting specimens listed below } \\
\hline $\begin{array}{c}\text { Seminal } \\
\text { plasma }\end{array}$ & $\begin{array}{c}\text { Accessory } \\
\text { glands } \\
\text { extract }\end{array}$ & $\begin{array}{c}\text { FV } \\
\begin{array}{c}\text { Sephadex } \\
G-100\end{array}\end{array}$ & $\begin{array}{c}\text { Testis } \\
\text { extract }\end{array}$ & $\begin{array}{c}\text { Epididymis } \\
\text { extract }\end{array}$ & $\begin{array}{c}\text { Kidney } \\
\text { extract }\end{array}$ \\
\hline 256 & 256 & 128 & $<2$ & $<2$ & $<2$ \\
\hline
\end{tabular}

* Inhibition of reaction between sheep anti-rabbit semen serum ' $c$ ' at dilution corresponding to 8 agglutinating units and human red blood cells coated with FV Sephadex G-100 at $0.1 \%$, using as inhibitors various rabbit tissue extracts and fluids at an initial protein concentration of $0.5 \%$

$\dagger$ Other rabbit preparations tested were pooled extracts of vagina, bladder, uterus and brain; all were negative as inhibitors.

TABLE 2

TANNED CELL HAEMAGgLUTINATION TEST*

\begin{tabular}{l|c|c|c|c|c|c}
\hline \multicolumn{7}{c}{ Antiserum reciprocal titre against red blood cells coated with: } \\
\hline $\begin{array}{c}\text { Accessory } \\
\text { glands } \\
\text { extract }\end{array}$ & $\begin{array}{c}\text { Seminal } \\
\text { plasma }\end{array}$ & \multicolumn{4}{|c}{ Sephadex G-100 fractions of seminal plasma } \\
\hline 4000 & 8000 & 8000 & 4000 & $<8$ & $<8$ & $<8$ \\
\hline 4
\end{tabular}

* Reactions of Rabbit 134 anti-RSP (autoimmunized) against human red blood cells coated with extract of rabbit accessory glands, pooled rabbit seminal plasma and its corresponding Sephadex G-100 fractions at $0.1 \%$ protein concentration.

\section{Autoantigenicity}

Tanned cells, sensitized with accessory glands' extract, seminal plasma and several Sephadex G-100 fractions of seminal plasma, were tested against Rabbit 134 anti-RSP serum. The results are shown in Table 2. It can be seen that positive reactions were obtained with accessory glands' extract, seminal plasma and FI and FII. By contrast, the reaction was negative $(<1: 8)$ when FIII, FIV and FV were used as coating material. Qualitatively comparable results were obtained using antisera from other rabbits (109, 113, 126 and 135) autoimmunized with seminal plasma.

Since the above experiments suggested that two antigens were involved in the reaction, confirmation was sought using inhibition of the haemagglutination technique. Results were not conclusive until FII, used as inhibitor, was further purified through columns of DEAE Sephadex A-50. Text-figure 1 shows a 
characteristic elution profile and the corresponding experimental conditions. The direct passive haemagglutination technique using Rabbit 134 antiserum proved that near optimal coating concentration was obtained at $0.01 \%$ and $0.001 \%$ for FI and purified FII, respectively. Inhibition experiments demonstrated that the reaction of autoantiserum 134 against red cells coated with FI at optimal concentration was not inhibited by purified FII used in a wide range of concentrations $\left(0.5\right.$ to $\left.3 \times 10^{-5} \mathrm{~g} \%\right)$ whereas the homologous material inhibited up to $0.5 \times 10^{-3} \mathrm{~g} \%$. Additional immunodiffusion experiments were performed in order further to explore this question. Plate 1, Fig. 5 shows a representative experiment where it can be seen that seminal plasma (wells 1 and 4) formed two

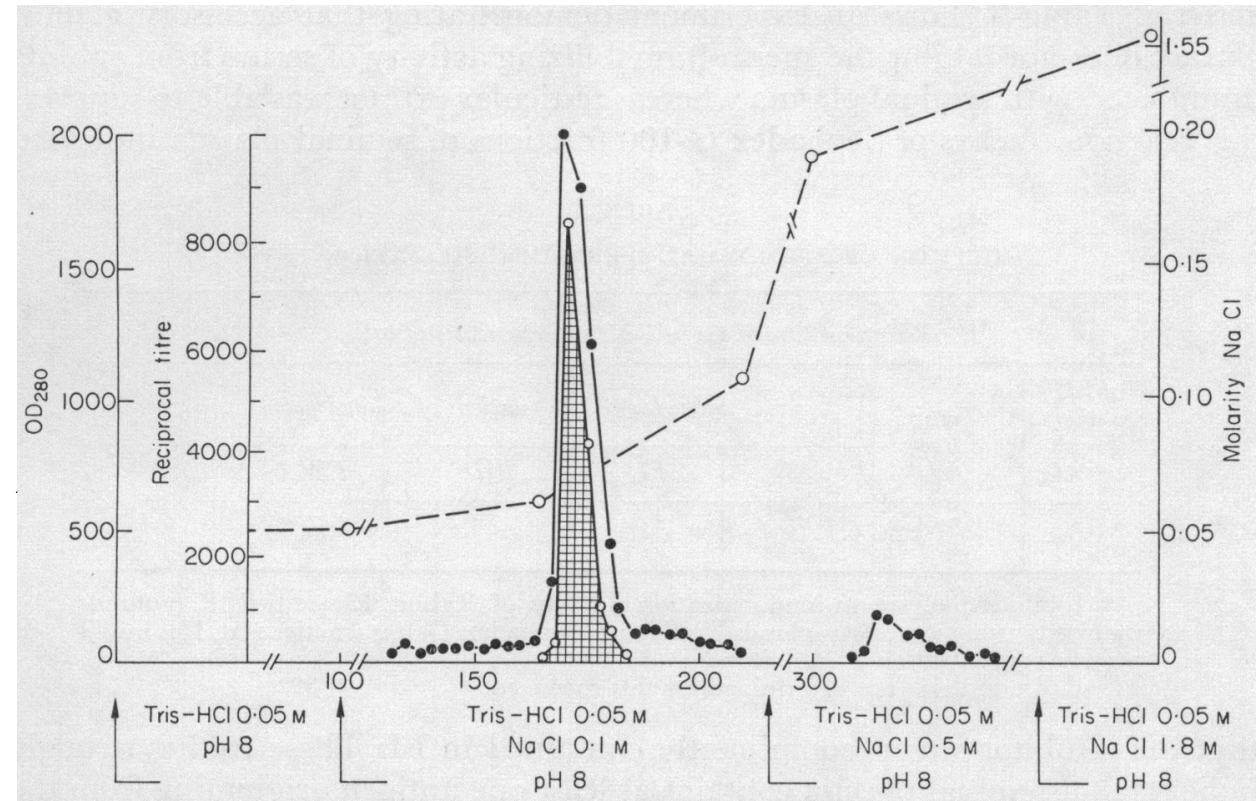

TExT-FIG. 1. DEAE-Sephadex A-50 stepwise elution pattern of $50 \mathrm{mg}$ Sephadex G-100 FII. Bed dimensions: $1.5 \times 50 \mathrm{~cm}$. Eluants: buffers as indicated. Flow rate: 6 to $8 \mathrm{ml} / \mathrm{hr}$. Effluent portions: $3 \mathrm{ml}$; (O) $\mathrm{OD}$ at $280 \mathrm{~m} \mu$; $O, \mathrm{NaCl}$ molarity. The shaded area corresponds to the distribution of the rabbit male accessory glands' autoantigen as measured by inhibition of haemagglutination.

precipitation lines when tested against Rabbit 171 anti-RSP. This experiment also shows that the line which is close to the antigens' well gave a common identity reaction with that corresponding to FI assayed at two different concentrations. The second line formed by seminal plasma coalesced in a pattern of complete identity with the band corresponding to FII. In a number of immunodiffusion studies, rabbit male accessory glands' extract showed two bands of precipitation which fused in a pattern of identity with that formed by seminal plasma when both antigenic materials were used at appropriate concentrations and diffused against either Rabbit 134 or Rabbit 171 antisera.

As semen consists of testicular products with epididymal and accessory glands' secretions, a number of experiments were devoted to the comparison of these organ extracts with seminal plasma. Immunodiffusion assays demonstrated the presence of a testicular autoantigen in RSP. This was achieved 
using sera of rabbits autoimmunized with native or chemically modified RSP which reacted against testicular extract forming a single precipitation line unrelated to the autoantigens described above, judging from the pattern of nonidentity observed when both systems were assayed simultaneously.

The complex autoantigenic nature of seminal plasma was further demonstrated by serological studies performed using epididymal spermatozoa. In effect, sperm-immobilizing activity was found in sera from four out of six rabbits immunized with native RSP and four out of four animals immunized with chemically modified RSP. By contrast, none of four animals injected with isologous accessory glands' extract showed positive sperm-immobilizing activity. Table 3 shows an experiment demonstrating that accessory glands' extract does not inhibit the sperm-immobilizing activity of serum from rabbits immunized with seminal plasma whereas testicular extract was able to suppress this reaction. Assays of Sephadex G-100 fractions of seminal plasma indicated

TABLE 3

INHIBITION OF EPIDIDYMAL SPERM-IMMOBILIZATION TEST*

\begin{tabular}{c|c|c|c|c|c|c}
\hline \multicolumn{6}{c}{ Reciprocal titre of the inhibiting specimens listed below } \\
\hline $\begin{array}{c}\text { Adult } \\
\text { accessory } \\
\text { glands } \\
\text { extract }\end{array}$ & $\begin{array}{c}\text { Testis } \\
\text { extract }\end{array}$ & \multicolumn{5}{|c}{ Sephadex G-100 fractions of seminal plasma } \\
\hline$<1$ & $5 \dagger$ & 75 & 10 & $<1$ & $<1$ & $<1$ \\
\hline$<1$ & $5 \dagger$ & $F I I$ & $F I I I$ & $F I V$ & $F V$ \\
\hline
\end{tabular}

* Inhibition of sperm-immobilization activity of Rabbit 134 anti-RSP (autoimmunized) using accessory glands, testis and Sephadex G-100 fractions at $1 \%$ initial protein concentration as inhibitors.

$\uparrow$ End point was not determined for this specimen.

that the inhibitor was predominantly contained in FI. These studies strongly indicate that seminal plasma contains at least one antigen originating from the epididymis or testis, which is responsible for the induction of sperm-immobilizing antibodies.

\section{DISGUSSION}

Ultracentrifugal analysis suggested a predominance of low molecular weight components in RSP. It is interesting to compare these results with those observed in human semen (Shulman, Bronson, Gonder \& Soanes, 1963), dog prostatic fluid (Yantorno, Shulman, Gonder, Soanes \& Witebsky, 1966) and guinea-pig vesicular fluid (Shulman, 1970) where predominant low sedimentation coefficient components were described. The heterogeneity of RSP was better demonstrated using chromatography on Sephadex G-100. The elution profile indicated a wide range of low molecular size components. The study of RSP electrophoretic properties was first attempted by Kirton et al. (1966) using the Tiselius apparatus. These authors reported at least seven or eight components, and also noted marked differences between blood serum and seminal plasma. More recently, Hunter \& Nornes (1969) reported at least twelve protein discs, separated by vertical gel electrophoresis in polyacrylamide. Using a 
similar procedure to the one described by these authors, we found comparable patterns comprising fourteen or more protein components.

Several authors had reported the antigenic heterogeneity of RSP (Weil \& Finkler, 1958; Menge \& Protzman, 1967; Hunter, 1969). In the present work, fourteen antigenic components were described when chromatographic fractions of Sephadex G-100 were tested by immunodiffusion. Besides, the studies accomplished using individual samples of RSP indicated that major antigens are present in all individuals. On the other hand, twelve antigenic components were detected using an immunoelectrophoretic technique in close accordance with the description of Menge \& Protzman (1967) and Hunter \& Nornes (1969).

Immunochemical analyses in connection with the tissue specificity of antigens from rabbit semen have been limited to the genital tract, although sperm-specific antigens have been described (Menge \& Protzman, 1967; Hunter, 1969). These observations were confirmed and enlarged in our studies, demonstrating that the antigens which characterize RSP constitute a mixture of antigens from several organs. Careful search involving a wide variety of tissues proved that some of these antigens were highly organ specific. Additionally, serum-like antigens, including IgG, were consistently observed in individual samples of rabbit semen. Symons \& Herbert (1971) recently reported that rabbit seminal plasma contained a variable quantity of IgG globulin.

Perhaps one of the most remarkable properties of an antigen is its ability to evoke autoantibodies. Studies utilizing antiserum raised in heterologous animals describe macromolecules which are not necessarily operative in autologous or isologous systems. Consequently, studies which aim to be of unequivocal relevance in problems of autoimmunity and/or infertility should require the use of antisera raised within the species. It has been firmly established that RSP and accessory glands contain a common autoantigen(s) (Shulman et al., 1966; Shulman, Riera \& Yantorno, 1968). In our studies, this finding has been confirmed and further developed to prove that the male accessory glands' autoantigenicity is provided by two antigens which can be immunochemically characterized. It should be noted that these autoantigens have been identified as organ- and species-specific (Shulman et al., 1966; Shulman, Brandt \& Yantorno, 1968; Yantorno, Riera \& Vottero-Cima, 1970). Additionally, it was demonstrated that RSP contains testicular autoantigen(s). This observation is consistent with a recent report dealing with the induction of autoimmune orchitis in the rabbit (Yantorno, Debanne \& Vottero-Cima, 1971) and could be related to the antifertility antibodies reported by Bell (1969).

\section{ACKNOWLEDGMENTS}

The authors would like to thank Dr Luis Glemente Patrito for performing the polyacrylamide gel electrophoresis studies and Mrs E. Baduy-Antun for preparation of the manuscript.

\section{REFERENCES}

BELL, E. B. (1969) Iso-antibody formation against rabbit spermatozoa and its effect on fertility. J. Reprod. Fert. 20, 519. 
Boyden, S. V. (1951) The absorption of proteins on erythrocytes treated with tannic acid and subssequent hemagglutination with antiprotein sera. F. exp. Med. 93, 107.

Bredderman, P. J., Foote, R. H. \& Yassen, A. M. (1964) An improved artificial vagina for collecting rabbit semen. F. Reprod. Fiert. 7, 401.

Davis, B. J. (1964) Disc electrophoresis. II. Method and application to human serum proteins. Ann. N.Y. Acad. Sci. 121, 404 .

Hunter, A. G. (1969) Differentiation of rabbit sperm antigens from those of seminal plasma. $\mathcal{F}$. Reprod. Fert. 20, 413.

Hunter, A. G. \& NorNes, H. O. (1969) Characterization and isolation of a sperm-coating antigen from rabbit seminal plasma with capacity to block fertilization. F. Reprod. Fert. 20, 419.

Killander, J. (1964) Separation of human heme- and hemoglobin-binding plasma proteins, ceruloplasmin and albumin by gel filtration. Biochim. biophys. Acta, 93, 1 .

Kirton, K. T., Desjardins, G. \& Hafs, H. D. (1966) Levels of some normal constituents of rabbit semen during repetitive ejaculation. Fert. Steril. 17, 204.

KoRngold, L. \& VAN LEEVWEN, G. (1957) The effect of the antigens molecular weight on the curvature of the precipiting line in the Ouchterlony technic. F. Immun. 78, 172.

Levy, H. B. \& Sober, H. A. (1960) A simple chromatographic method for preparation of gamma globulin. Proc. Soc. exp. Biol. Med. 103, 250.

Menge, A. C. \& Protzman, W. P. (1967) Origin of the antigens in rabbit semen which induce antifertility antibodies. F. Reprod. Fert. 13, 31 .

OUCHTERLONY, O.(1948) In vitro method for testing the toxic-producing capacity of diphtheria bacteria. Acta path. microbiol. scand. 25, 186.

ScheidegGer, J. J. (1955) Une micro-méthode de l'immune électrophorèse. Int. Archs Allergy appl. Immun. 7, 103.

Shulman, S. (1970) Les autoantigénes de la vésicule séminale. Annls Inst. Pasteur, Paris, 118, 529.

Shulman, S., Brandt, E. J. \& Yantorno, C. (1968) Studies in cryo-immunology II. Tissue and species specificity of the autoantibody response and comparison with iso-immunization. Immunology, 14, 149.

Shulman, S., Bronson, P., Gonder, M. J. \& Soanes, W. A. (1963) Ultracentrifugal constituents of human and canine prostatic fluid. Nature, Lond. 197, 58.

Shulman, S., Riera, C. \& Yantorno, G. (1968) Studies on organ specificity. XIX. Antigenic specificity of seminal plasma and the formation of autoantibodies. $\mathcal{F}$. Immun. 100, 682.

Shulman, S., Yantorno, G., Soanes, W. A., Gonder, M. J. \& Witebsky, C. (1966) Studies on organ specificity. XVI. Urogenital tissues and autoantibodies. Immunology, 10, 99.

SMITHIEs, O. (1959) An improved procedure for starch-gel electrophoresis. Further variations in the serum protein of normal individuals. Biochem. 7. 71, 585 .

Symons, D. B. A. \& Herbert, J. (1971) Incidence of immunoglobulins in fluids of the rabbit genital tracts and the distribution of IgG-globulin in the tissues of the female tract. F. Reprod. Fert. 24, 55 .

VIDes, M. A. (1969) Estudios immunoquímicos del plasma seminal de conejo. Aislamiento y purificación de un autoantigeno. Tesis, Instituto de Ciencias Químicas. Universidad Nacional de Córdoba. Argentina.

Weil, A. J. \& Finkler, A. E. (1958) Antigens of rabbit semen. Proc. Soc. exp. Biol. Med. 98, 794.

WeIL, A. J. \& Finkler, A. E. (1959) Isoantigenicity of rabbit semen. Proc. Soc. exp. Biol. Med. 102, 624.

Yantorno, C., Debanne, M. T. \& Vottero-Cima, E. (1971) Autoimmune orchitis induced by autoimmunization with seminal plasma in rabbit. F. Reprod. Fert. 27, 311.

YANTORNo, C., Riera, C. \& VotTero-Cima, E. (1970) Especificidad común de la crio e iso-immunización con glándulas sexuales de conejo. In: Alergia e Inmunología, page 347. Eds C. A. Mathov, J. Schechtman, J. Bacigaluppi and N. Raimondo. Bs. As. Argentina.

Yantorno, C., Shulman, S., Gonder, M. J., Soanes, W. A. \& Witebsky, S. (1966) Studies on organ specificity. XVIII. Immunologic and biophysical characterization of canine prostatic fluid. f. Immun. 96, 1035.

Yantorno, G., Soanes, W. A., Gonder, M. J. \& Shulman, S. (1967) Studies in cryo-immunology. I. The production of antibodies to urogenital tissue in consequence of freezing treatment. $I m$ munology, 12, 395. 